\title{
Perbandingan Rapid Diagnostic Test dan Pemeriksaan Mikroskopik pada Diagnosis Malaria
}

\section{Comparative of Rapid Diagnostic Test with Microscopy to Diagnose Malaria Diseases}

\section{Lambok Siahaan}

Departemen Parasitologi Fakultas Kedokteran Universitas Sumatera Utara

\begin{abstract}
Abstrak
Penelitian ini dilakukan untuk membandingkan penggunaan Rapid diagnostic test dengan pemeriksaan mikroskopik (apusan darah) dalam menegakkan diagnosis malaria. Penelitian uji diagnostik ini dilakukan di Kabupaten Nias Selatan dan Kotamadya Sabang, Sumatera Utara. Apusan darah diwarnai dengan larutan Giemsa $10 \%$ dan dibaca oleh pemeriksa yang sudah terlatih. Rapid diagnostic test dilakukan dengan menggunakan parascreen. Uji diagnostik rapid diagnostic test secara umum diperoleh hasil yaitu sensitivitas $63,8 \%$; spesifisitas $100 \%$; Positive Predictive Value (PPV) 100\%; dan negative predictive value (NPV) $93,5 \%$. Kepadatan parasit pada rapid diagnostic test (+) dan mikroskopik $(+)$ adalah $1.483 \pm 583$ parasit/ $\mu$ l. Sementara, kepadatan parasit pada pemeriksaan rapid diagnostic test (-) dan mikroskopik (+) adalah $621 \pm$ 335 parasit/ul. Pemeriksaan mikroskopik masih lebih baik dibandingkan dengan rapid diagnostic test, terutama pada kepadatan parasit yang rendah.
\end{abstract}

Kata kunci: Malaria, pemeriksaan mikroskopik, rapid diagnostic test

\footnotetext{
Abstract

The study was conducted to compare rapid diagnostic test with microscopy (blood film) to diagnose malaria disease. This diagnostic test was done in South of Nias District and Sabang District, North Sumatera. Blood film were colored with Giemsa 10\% solution and examined by trained microscopists. Rapid Diagnostic Test was done based on the manual procedure. The results of diagnostic test of rapid diagnostic test were sensitivity $63,5 \%$; specificity $100 \%$, positive predictive value (PPV) $100 \%$, and negative predictive value (NPV) $93,5 \%$. The density of parasite in rapid diagnostic test (+) were $1.483 \pm 583$ parasite/ $\mu$ l (1.120-2.920 parasite/ $\mu$ l. In other hand, the density of parasite in rapid diagnostic test (-) and microscopy were $621+335$ parasite/ $\mu \mathrm{l}$ (120-1.160 parasite/ $\mu \mathrm{l})$. Microscopy still better than rapid diagnostic test, especially in patient with low parasite density.
}

Keywords: Malaria, microscopic examination, rapid diagnostic test

\section{Pendahuluan}

Hingga saat ini, malaria masih merupakan masalah kesehatan masyarakat yang serius, khususnya bagi daerah tropis dan subtropis. Diperkirakan 2,5 milyar manusia hidup di wilayah-wilayah endemis malaria dengan sekitar 300 juta kasus kesakitan dan 1 juta kematian yang sebagian besar adalah anak-anak. Jika wilayah endemis malaria tersebut tidak ditanggulangi secara serius dapat dipastikan bahwa risiko penduduk tertular malaria akan semakin besar. Oleh karena itu, World Health Organization menempatkan malaria sebagai prioritas utama program penanggulangan dan penelitian penyakit tropis. Sekitar 275 juta dari 500 juta penduduk terinfeksi malaria di wilayah Afrika Selatan Gunung Sahara, 100 juta diantaranya dengan gejala klinis. Setiap tahun, biaya untuk malaria lebih dari US\$ 12 milyar yang merupakan $40 \%$ dari seluruh biaya kesehatan masyarakat. Pertumbuhan ekonomi di berbagai negara dengan prevalensi malaria yang tinggi jauh lebih rendah daripada negara yang tanpa malaria. Sekitar 100 ribu kasus kematian akibat malaria terjadi setiap tahun di luar Afrika. 1,2

Malaria tidak pernah tereradikasi dan mengalami pasang surut dari tahun ke tahun di Indonesia. Periode tahun 1997-2000, angka kesakitan malaria mengalami peningkatan yang tajam. Annual Parasite Incidence (API) di Jawa-Bali pada tahun 1997 (0,12\%o), tahun 1999 (0,52\%o), dan $2000(0,81 \%$ ) memperlihatkan tren peningkatan yang pesat. Annual Malaria Incidence tahun

Alamat Korespondensi: Lambok Siahaan, Departemen Parasitologi Fakultas Kedokteran Universitas Sumatera Utara, Jl. Dr. Mansyur No. 5 Medan, Hp.08126561772,e-mail: lambok_fkusu@yahoo.com 
$1997(16,06 \%), 2000(31,09 \%)$ juga terlihat meningkat. Selama periode tersebut, malaria telah menyebabkan kejadian luar biasa (KLB) di 121 desa, 42 kabupaten dan 11 provinsi dengan jumlah penderita 29.345 orang dan meninggal 483 orang $(\mathrm{CFR}=1,65 \%){ }^{3}$ Periode 2001-2004, angka kesakitan malaria mengalami penurunan. API pada tahun $2001(0,62 \%$ o) dan 2004 $(0,15 \%$ memperlihatkan tren penurunan yang pesat di Jawa Bali. AMI pada tahun 2001 (26,20 \%o) dan 2004 $(21,20 \%)$ terlihat menurun di luar Jawa Bali. KLB malaria terjadi di 7 provinsi meliputi Jawa Barat, Jawa Timur, Sumatera Barat, Maluku Utara, Kalimantan Barat, D.I. Yogyakarta, dan Lampung yang menyebabkan 3.267 kasus dengan 11 kematian pada tahun 2003. Terjadi KLB di 5 provinsi yang mencakup 6 kabupaten dengan 1.959 penderita dan 33 kematian pada tahun $2004 .^{4}$

Malaria masih merupakan masalah kesehatan di Sumatera Utara. Sebagai contoh, kejadian malaria di Kabupaten Nias Selatan Sumatera Utara berdasarkan hasil pemeriksaan darah dihasilkan bahwa 52\% dari 731 sampel dinyatakan positif malaria. ${ }^{5}$ Angka kesakitan dan kematian akibat malaria yang tinggi umumnya terjadi karena keterlambatan diagnosis dan resistensi antimalaria. Keterlambatan diagnosis sangat dipengaruhi oleh ketersediaan alat bantu diagnosis yang tersedia di suatu daerah tertentu. Gejala klinis yang secara spesifik ditemukan di daerah endemis malaria, yang dapat digunakan sebagai langkah awal menegakkan diagnostik malaria klinis, sangat membantu dalam penanganan penyakit malaria secara cepat, tepat, dan rasional. Namun, diagnosis malaria klinis harus dikonfirmasi dengan hasil pemeriksaan apusan darah (mikroskopik) yang masih menjadi gold standard dalam diagnosis malaria. ${ }^{6}$ Kekurangan tenaga laboratorium kesehatan yang terampil menggunakan mikroskop untuk menegakkan diagnosis malaria secara tepat merupakan salah satu penyebab keterlambatan pengobatan dan kesalahan diagnosis malaria.

Sebagai salah satu metode pemeriksaan alternatif yang relatif mudah digunakan adalah pemeriksaan dengan rapid diagnostic test. Namun, tingkat sensitivitas dan spesifisitas pemeriksaan tersebut yang bervariasi di berbagai tempat sehingga hal tersebut merupakan suatu yang menarik dan perlu untuk diteliti. ${ }^{7}$ Sebagai pembanding digunakan pemeriksaan asupan darah (mikroskopik). Penelitian yang dilakukan ini bertujuan untuk membandingkan hasil pemeriksaan rapid diagnostic test dengan pemeriksaan asupan darah (mikroskopik) pada penderita malaria di daerah endemis malaria. Hasil yang diperoleh diharapkan dapat menjadi pertimbangan dalam menegakkan diagnosis penyakit yang berhubungan dengan laporan prevalensi penyakit malaria di suatu daerah tertentu.
Tabel 1. Karakteristik Sampel Penelitian

\begin{tabular}{llll}
\hline Karakteristik & Kategori & n & $\%$ \\
\hline Kelompok umur & $<5$ tahun & 55 & 8,4 \\
& $5-12$ tahun & 76 & 11,6 \\
& $15-24$ tahun & 83 & 12,7 \\
& $25-34$ tahun & 100 & 15,2 \\
& $35-44$ tahun & 114 & 17,4 \\
& $45-54$ tahun & 117 & 17,8 \\
& $>55$ tahun & 111 & 16,9 \\
Jenis kelamin & Perempuan & 355 & 54,1 \\
& Laki-laki & 301 & 45,9 \\
\hline
\end{tabular}

Tabel 2. Hasil Uji Diagnosis

\begin{tabular}{lccc}
\hline \multirow{2}{*}{ Rapid Diagnostic } & \multicolumn{2}{c}{ Mikroskopik } & Total Tes \\
\cline { 2 - 3 } & Positif & Negatif & \\
\hline Positif & 67 & 0 & 67 \\
Negatif & 38 & 551 & 589 \\
\hline Total & $\mathbf{1 0 5}$ & $\mathbf{5 5 1}$ & $\mathbf{6 5 6}$ \\
\hline
\end{tabular}

Tabel 3. Perbandingan Kepadatan Parasit

\begin{tabular}{lll}
\hline \multirow{2}{*}{ Pemeriksaan } & \multicolumn{2}{c}{ Kepadatan Parasit (/ml) } \\
\cline { 2 - 3 } & Mean & \multicolumn{1}{c}{ SD } \\
\hline RDT (+) dan mikroskopik (+) & 1.483 & $583,46(1.120-2.920)$ \\
RDT (-) dan mikroskopik (+) & 621 & $334,81(120-1.160)$ \\
\hline
\end{tabular}

\section{Metode}

Penelitian ini dilaksanakan di Kotamadya Sabang dan Kabupaten Nias Selatan, Provinsi Sumatera Utara. Populasi penelitian adalah penduduk yang bertempat tinggal di lokasi penelitian terpilih yang merupakan daerah endemis malaria. Populasi terjangkau adalah pasien dengan keluhan demam atau riwayat demam dalam periode satu minggu terakhir. Setiap populasi terjangkau akan dilakukan pemeriksaan rapid diagnostic test (parascreen) dan pemeriksaan sediaan apusan darah tepi (mikroskopis). Penderita malaria yang disertakan dalam penelitian ini adalah penderita malaria yang diakibatkan oleh Plasmodium falciparum dan Plasmodium vivax.

\section{Hasil}

Penderita suspek malaria yang disertakan dan diperiksa dalam penelitian ini adalah 656 orang yang dikelompokkan berdasarkan kelompok umur kurang dari 5 tahun sampai lebih dari 55 tahun. Kelompok kasus terendah adalah pada anak usia kurang dari 5 tahun dan anak 
sekolah yaitu usia 5-12 tahun dan terbanyak dijumpai pada kelompok dewasa yaitu usia 45-54 tahun. Sementara itu, kasus perempuan $(54,1 \%)$ sedikit lebih banyak dijumpai daripada kasus laki-laki (45,9\%) (Lihat Tabel 1).

Berdasarkan perhitungan hasil uji diagnosis rapid diagnostic test tersebut, diperoleh hasil indikator skrining yaitu kemampuan uji rapid diagnostic test untuk menentukan diagnosis malaria secara benar (sensitivitas) adalah 67/105 (63,8\%), sedangkan kemampuan uji rapid diagnostic test untuk menegakkan diagnosa bukan malaria secara benar (spesifisitas) adalah $551 / 551(100 \%)$. Selain itu, kemampuan untuk memprediksi penderita malaria secara benar atau positive predictive value (PPV) adalah 67/67 (100\%), sedangkan kemampuan untuk memprediksi bukan penderita malaria secara benar atau negative predictive value (NPV) adalah 551/589 (93,5\%) (Lihat Tabel 2).

Sensitivitas rapid diagnostic test pada penelitian ini sangat dipengaruhi oleh kepadatan parasit. Umumnya, kepadatan parasit pada pemeriksaan rapid diagnostic test (+) dan mikroskopis (+) relatif lebih tinggi jika dibandingkan dengan rapid diagnostic test (-) dan mikroskopis (+) (Lihat Tabel 3).

\section{Pembahasan}

Hasil yang diperoleh pada penelitian ini umumnya hampir sama dengan penelitian-penelitian yang dilakukan di daerah endemis malaria lain yang menemukan nilai sensitivitas pemeriksaan rapid diagnostic test rendah, walaupun spesifitasnya masih tergolong baik. ${ }^{8,9}$ Bahkan, penelitian yang dilakukan oleh VanderJagt, ${ }^{10}$ mendapatkan hasil sensitivitas rapid diagnostic test yang kurang dari $50 \%$.

Penelitian ini juga didapatkan hasil bahwa sensitivitas rapid diagnostic test dipengaruhi oleh kepadatan parasit. Pada kepadatan parasit yang rendah, sensitivitas rapid diagnostic test menjadi berkurang $(<500$ parasit/ml). Hal yang sama juga diperoleh pada penelitian lainnya. ${ }^{11,12}$ Kelemahan rapid diagnostic test tersebut pada dasarnya dapat diantisipasi dengan cara mengikuti petunjuk penyimpanan dan penggunaan alat sesuai dengan anjuran. Seleksi pasien berdasarkan gejala dan tanda klinis malaria juga dapat membantu meningkatkan sensitivitas rapid diagnostic test. ${ }^{9}$ Penelitian ini tidak ditemukan hasil yang false positive, seperti yang diperoleh oleh Coleman, ${ }^{11}$ pada penelitian mereka.

Berbeda dengan penelitian di daerah endemis, penelitian di luar daerah endemis malaria menunjukkan hasil yang berbeda. Verle dkk, ${ }^{13}$ mendapatkan bahwa sensitivitas rapid diagnostic test dapat mencapai $100 \%$, walaupun spesifisitasnya hanya $88 \%$. Hasil penelitian rapid diagnostic test lainnya menyatakan bahwa rapid diagnostic test tidak dianjurkan untuk pemeriksaan follow-up penderita malaria. Hal ini disebabkan oleh masih ditemukan antibodi terhadap antigen malaria pada tubuh penderita selama masa tersebut. ${ }^{14}$ Tampaknya, penggunaan rapid diagnostic test sebagai alat pemeriksaan malaria alternatif sangat perlu dilakukan evaluasi secara berkala. Penurunan sensitivitas rapid diagnostic test yang terdeteksi secara dini dapat mengurangi terjadi false negative, khususnya di daerah endemis malaria. ${ }^{8}$

\section{Kesimpulan}

Pemeriksaan mikroskopik memperlihatkan hasil yang lebih baik dibandingkan dengan rapid diagnostic test, terutama untuk kepadatan parasit yang rendah. rapid diagnostic test memperlihatkan kelemahan untuk digunakan sebagai metode pemeriksaan malaria alternatif, tetapi rapid diagnostic test masih tetap sangat diperlukan, terutama di daerah yang kekurangan tenaga laboratorium dan untuk kepentingan surveilans.

\section{Daftar Pustaka}

1. World Health Organization. Malaria in Africa. [14 Mei 2006]. Available from: http://www.rbm.who.int/cmcupload/0/000/015/370/ RBMInfosheet3.htm.

2. Sutisna P. Malaria secara ringkas dari pengetahuan dasar sampai terapan. Jakarta: Buku Kedokteran ECG; 2004.

3. Departemen Kesehatan Republik Indonesia. Profil kesehatan Indonesia 2000. Jakarta: Departemen Kesehatan Republik Indonesia; 2001.

4. Departemen Kesehatan RI. Status kesehatan masyarakat Indonesia survei. Jakarta: Departemen Kesehatan Republik Indonesia; 2001

5. Siahaan L. Malaria vivax di Kabupaten Nias Selatan. Kesmas Jurnal Kesehatan Masyarakat Nasional. 2008; 3 (1): 45-8

6. World Health Organization. New perspectives malaria diagnosis. 1999. p. 11.

7. Moody A. Rapid diagnostic tests for malaria parasites. Clinical Microbiology Reviews. 2002; 15 (1): 66-78.

8. Belizario VY. Field evalution of malaria rapid diagnostic tests for the diagnostic of malaria. Southeast Asian Journal of Tropical Medicine and Public Health. 2005; 36 (3): 552.

9. Proux S, Hkirijareon L, Ngamngonkiri C, McConnell S, Nosten F. Paracheck-pf rs: a new, inexpensive, and reliable rapid test for p. falciparum malaria. Tropical Medicine and International Health. 2001; 6 (2): 99-101.

10. VanderJagt TA. Comparison of the optimal rapid test and microscopy for detection of malaria in pregnant women in Nigeria. Tropical Medicine and International Health. 2005; 10 (1): 39-41.

11. Coleman RE. Short report : failure of the optimal rapid malaria test as a toll for the detection of asymptomatic malaria in an area of Thailand endemic for plasmodium falciparum and plasmodium vivax. Am. J. Trop. Med. Hyg. 2002; 67(6): 563-5.

12. Gonul A, Mustafa U, Adnan S, Ozcan E. Diagnostic performance characteristics of rapid diagnostic test for plasmodium vivax malaria. Mem Inst Oswaldo Cruz. 2001; 96 (5): 683-6. 
13. Verle P, Binh LN, Lieu TT, Yen PT, Coosemans M. Parasight-f test to diagnose malaria in hypo-endemic and epidemic prone regions of Vietnam. Tropical Medicine and International Health. 1996; 1 (6): 794-6.
14. Huong NM. Comparison of three antigen detection methods for diagnosis and therapeutic monitoring of malaria: a field study from Southern Vietnam. Tropical Medicine and International Health. 2002; 7 (4): 3048. 